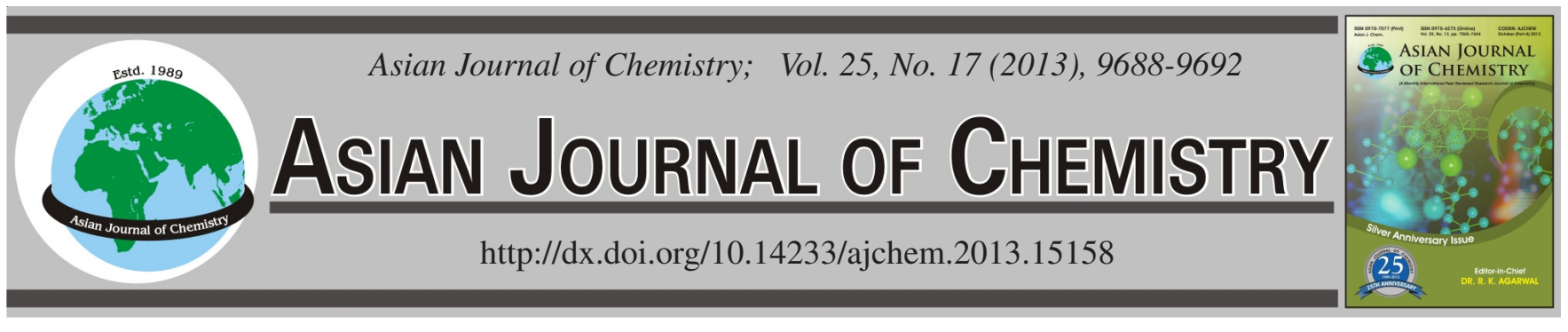

\title{
Synthesis, Structure Elucidation and Study of Antimicrobial Activity of Stannic(IV) Derivatives
}

SadiQ-ur-Rehman ${ }^{1}$, Saira Sherzaman ${ }^{1}$, Muhammad Aziz Choudhary $^{2, *}$, Muhammad Aslam Mirza $^{2}$ and Khawaja Ansar Yasin $^{1}$

${ }^{1}$ Department of Chemistry, University of Azad Jammu and Kashmir, Muzaffarabad-13100, Pakistan

${ }^{2}$ Department of Chemistry, Mirpur University of Science and Technology (MUST), Mirpur-10250, Pakistan

*Corresponding author: E-mail: azizch@yahoo.com

(Received: 16 January 2013;

Accepted: 14 October 2013)

AJC-14255

\begin{abstract}
Six new organotin(IV) compounds with general formulae $\mathrm{R}_{2} \mathrm{Sn}(\mathrm{OL})_{2}$ and $\mathrm{R}_{3} \mathrm{SnOL}$ where $\mathrm{R}=\mathrm{CH}_{3}, n-\mathrm{C}_{4} \mathrm{H}_{9}, \mathrm{C}_{6} \mathrm{H}_{5}$, OL $=4$-oxypiperidine were synthesized by the reaction of $\mathrm{R}_{2} \mathrm{SnCl}_{2}$ and $\mathrm{R}_{3} \mathrm{SnCl}$ with stoichiometric amount of 4-hydroxypiperidine in dry ethanol/methanol. These compounds have been characterized by using multinuclear $\left({ }^{1} \mathrm{H},{ }^{13} \mathrm{C},{ }^{119} \mathrm{Sn}\right)$ NMR and FT-IR spectroscopy. The spectroscopic results revealed that all the diorganotin(IV) compounds possess trigonal-bipyramidal geometry in solution and a tetrahedral environment around the tin atom in non-coordinating solvents, has been proposed for the triorganotin(IV) compounds. All the synthesized compounds were tested in vitro against a number of microorganisms to assess their biocidal activity. The biological activity of these compounds against various strains of bacteria and fungi has revealed promising activity in comparison with Amphotericin B and miconazole as reference drugs. $\mathrm{LD}_{50}$ values of some of the tested compounds showed cytotoxicity.
\end{abstract}

Key Words: Organotin, Biological activity, Organotin(IV) alkoxide.

\section{INTRODUCTION}

Organotin compounds are of current interest due to increase in their biological activities as well as industrial and agricultural applications ${ }^{1,2}$. There are now more organometallic compounds of tin in commercial use than any other element, covering a wide spectrum of biological and non-biological applications ${ }^{3,4}$. In general, the biochemical activity of organotin compounds is influenced remarkably by the coordination number of tin atoms ${ }^{5}$. Among organotin(IV) compounds, organotin(IV) carboxylates have been studied extensively for their antimicrobial, antiinflammatory and antituberculosis activities $^{5}$. In view of well known application and biological activities of organotin derivatives we are continuously involved in synthesis and characterization of organotin(IV) carboxylates ${ }^{6-8}$.

Recently, we have investigated organotin compounds containing alkoxide ligand 4-hydroxypiperidine with di- and triorganotin moieties and the result of this study are reported here in.

\section{EXPERIMENTAL}

Analytical grade organotin chlorides (dimethyltin dichloride, trimethyltin chloride, triphenyltin chloride, diphenyltin dichloride, tri- $n$-butyltin chloride, di- $n$-butyltin dichloride) were purchased from Aldrich. The ligand, 4-hydroxypiperidine was obtained from ACROS. Organic solvents used for synthesis like methanol, ethanol, toluene, chloroform, acetone and dimethyl sulfoxide were used of Merck, Germany and dried in situ using standard procedures ${ }^{9-11}$.

All other chemicals were of analytical grade and used without further purification.

Melting points were determined in a capillary tube using electrothermal melting point apparatus model MPD Mitamura Ricken Kogyo (Japan). The infrared absorption spectra were recorded as KBr pallets on a Bio-Red Merlin (USA) spectrometer in the frequency range $4000-400 \mathrm{~cm}^{-1}$. Multinuclear NMR $\left({ }^{1} \mathrm{H},{ }^{13} \mathrm{C},{ }^{119} \mathrm{Sn}\right)$ spectra were recorded on Bruker 300 $\mathrm{MHz}$, FT-NMR Spectrometer using $\mathrm{CDCl}_{3}$ as internal reference, $\left(\delta{ }^{1} \mathrm{H} \mathrm{CDCl}_{3}=7.27, \delta{ }^{13} \mathrm{C} \mathrm{CDCl}_{3}=77.6 \mathrm{ppm}\right)$. The elemental analysis was made on CHN-932 Elemental Analyzer Leco Corporation (USA).

General procedure for synthesis of organotin(IV) alkoxides: $\mathrm{R}_{2} \mathrm{SnOL}_{2}$ and $\mathrm{R}_{3} \mathrm{SnOL}$, complexes of organotin compounds were prepared by the reaction of ligand 4-hydroxypiperidine ( $1 \mathrm{~g}, 9.8 \mathrm{mmol}$ ) with organotin chlorides, $\mathrm{R}_{2} \mathrm{SnCl}_{2}$ $(0.5 \mathrm{~g}, 4.9 \mathrm{mmol})$ and $\mathrm{R}_{3} \mathrm{SnCl}(1 \mathrm{~g}, 9.8 \mathrm{mmol})$ in dry methanol $(25 \mathrm{~mL})$ in two-neck round bottom flask $(250 \mathrm{~mL})$ equipped with water condenser (Scheme-I). The reaction mixture was refluxed for $6 \mathrm{~h}$ and stirred over night at $273 \mathrm{~K}$. The resulting product was obtained by evaporating the mixture under reduce pressure on rotary evaporator. The solid product thus obtained was recrystallized from chloroform. 


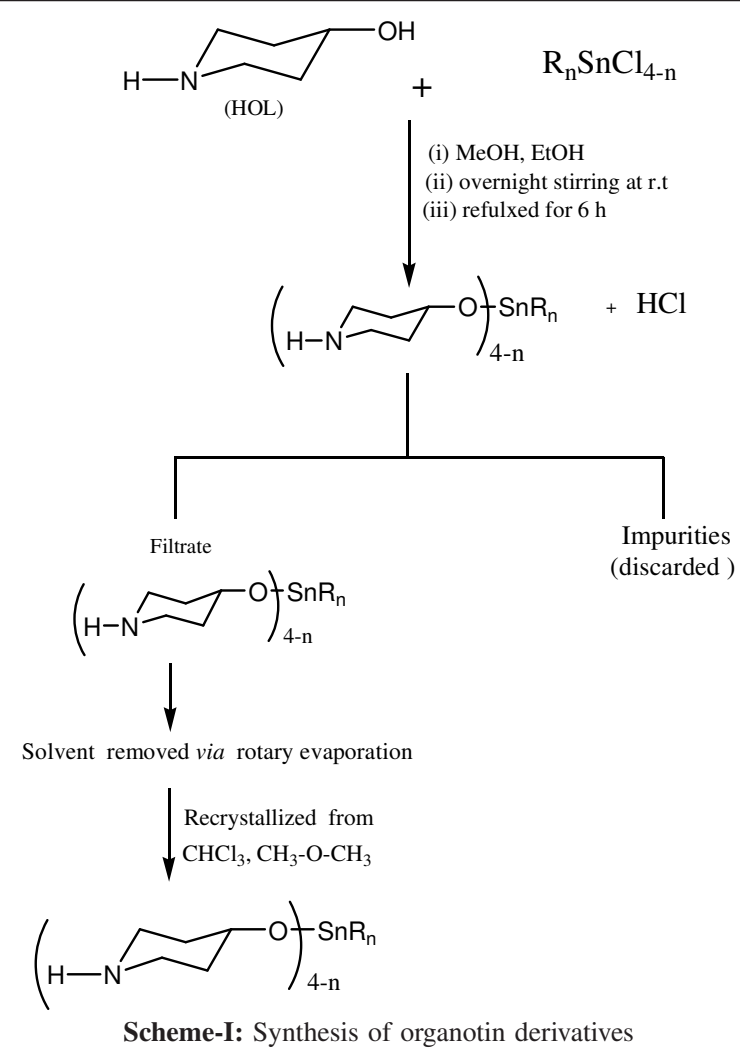

\section{RESULTS AND DISCUSSION}

Synthesis of organotin(IV) alkoxides: Organotin(IV) compounds of general formula $\mathrm{R}_{2} \mathrm{Sn}(\mathrm{OL})_{2}$ and $\mathrm{R}_{3} \mathrm{SnOL}$ were prepared from the corresponding di- and triorganotin chlorides by refluxing the stoichiometric amount of ligand HOL in (1:2) and $(1: 1)$ ratios in dry methanol for $6 \mathrm{~h}$. They are air stable and soluble in common organic solvents. To predict structures and other properties all compounds have been characterized by various analytical techniques IR, NMR $\left({ }^{1} \mathrm{H},{ }^{13} \mathrm{C},{ }^{119} \mathrm{Sn}\right)$ and were tested for their biological activity. The general Scheme-I depicted the procedure adopted for the synthesis of organotin(IV) alkoxides. The physical data are given in the Table-1.

Infrared spectroscopy: Vibrational data for synthesized compounds are given in Table-2. The coordination mode of the ligand, 4-hydroxypiperidine towards the di- and triorganotin(IV) moieties can be deduced by comparing infrared spectra of free ligand with synthesized compounds.

The explicit feature in the spectra of all complexes is absence of a band in the region $3602 \mathrm{~cm}^{-1}$, which appears in the free ligand as the $v(\mathrm{O}-\mathrm{H})$ vibration thus indicating metal-ligand bond formation through this site ${ }^{12}$. Diagnostically important IR bands are $v(\mathrm{O}-\mathrm{H}), \mathrm{v}(\mathrm{N}-\mathrm{H}) \mathrm{v}(\mathrm{Sn}-\mathrm{C})$ and $v(\mathrm{Sn}-\mathrm{O})$. The N-H
TABLE-2

INFRARED DATA $\left(\mathrm{cm}^{-1}\right)$ OF ORGANOTIN(IV) COMPLEXES WITH 4-HYDROXYPIPERIDINE

\begin{tabular}{lcccc}
\hline \multicolumn{1}{c}{ Compound. No. } & $v(\mathrm{O}-\mathrm{H})$ & $v(\mathrm{~N}-\mathrm{H})$ & $v(\mathrm{Sn}-\mathrm{C})$ & $v(\mathrm{Sn}-\mathrm{O})$ \\
\hline $\mathrm{LOH}$ & 3602 & 3292 & - & - \\
$\left.\mathrm{Me} \mathrm{Sn}_{2} \mathrm{OL}\right)_{2}(\mathrm{I})$ & - & 3400 & 550 & 463 \\
$\mathrm{Me}_{3} \mathrm{SnOL}(\mathrm{II})$ & - & 3416 & 559 & 428 \\
$n-\mathrm{Bu}_{2} \mathrm{Sn}(\mathrm{OL})_{2}(\mathrm{III})$ & - & 3460 & 567 & 480 \\
$n-\mathrm{Bu} 3 \mathrm{SnOL}(\mathrm{IV})$ & - & 3369 & 518 & 450 \\
$\mathrm{Ph}_{2} \mathrm{Sn}(\mathrm{OL})_{2}(\mathrm{~V})$ & - & 3441 & 579 & 446 \\
$\mathrm{Ph}_{3} \mathrm{SnOL}(\mathrm{VI})$ & - & 3416 & 523 & 466 \\
\hline
\end{tabular}

stretching frequencies, $3500-3200 \mathrm{~cm}^{-1}$ in the complexes approximately remain the same in comparison with free ligand (Table-2). The disappearance of $\mathrm{v}(\mathrm{O}-\mathrm{H})$ stretching band and appearance of absorption band for the $\mathrm{Sn}-\mathrm{O}$ bond in the range of $480-420 \mathrm{~cm}^{-1}$ reflect the formation of complexes ${ }^{13}$. The band $\mathrm{Sn}-\mathrm{C}$ bond appears in the region $625-520 \mathrm{~cm}^{-114}$. These results suggest that the tin atom in both of the di- and triorganotin complexes adopt a tetrahedral geometry in solid state ${ }^{15}$.

${ }^{1}$ H NMR spectroscopy: ${ }^{1} \mathrm{H}$ NMR spectra of all the compounds have been recorded on $300 \mathrm{MHz}$ Bruker, FT-NMR spectrometer. The characteristic resonance peaks in the ${ }^{1} \mathrm{H}$ NMR spectra for complexes (II, III, IV and VI) and free ligand HOL are listed in the Table-3. The assignment is made on the basis of peak multiplicity, intensity pattern, integration, tin satellites and by comparing with literature values ${ }^{16}$. The integration of spectra showed good agreement with the composition of compounds. In the spectrum of free ligand, $\mathrm{OH}$ and $\mathrm{NH}$ protons resonate, respectively at 4.94 and $4.11 \mathrm{ppm}$ as singlets, while the signals for equatorial and axial protons of the ligand moiety with their distinct multiplicities have been assigned according to the literature ${ }^{16}$. The analogous pattern of the signals, rather similar positions of the protons has been observed for the investigated tin compounds ${ }^{17,18}$.

In trimethyltin(IV) compound (II) $\mathrm{CH}_{3}$ protons appeared as sharp singlet at $0.50 \mathrm{ppm}$ with well resolved ${ }^{2} J\left[{ }^{119} \mathrm{Sn},{ }^{1} \mathrm{H}\right]$ coupling constant $68 \mathrm{~Hz}$, which propose tetrahedral geometry around tin in solution ${ }^{17}$. The $n$-butyltin (IV) derivatives (III, IV) show a clear triplet due to a methylenic group, which appears at 1.69 and $1.70 \mathrm{ppm}$, with well defined ${ }^{2} J\left[{ }^{119} \mathrm{Sn},{ }^{1} \mathrm{H}\right]$ couplings constants of 82 and $63 \mathrm{~Hz}$, respectively ${ }^{19-21}$. The ${ }^{2} J\left[{ }^{119} \mathrm{Sn},{ }^{1} \mathrm{H}\right]$ couplings constants of $82 \mathrm{~Hz}$ suggest more than four coordination around tin in solution whereas the ${ }^{2} J\left[{ }^{119} \mathrm{Sn}\right.$, $\left.{ }^{1} \mathrm{H}\right]$ couplings constants of $63 \mathrm{~Hz}$ support tetrahedral geometry around tin in solution for compound (IV $)^{19-21}$. The terminal methyl group of (III, IV) appears at $0.95 \mathrm{ppm}$ as triplet showing ${ }^{3} J\left[{ }^{1} \mathrm{H},{ }^{1} \mathrm{H}\right)$ coupling constants at 7.4 and $7.2 \mathrm{~Hz}$, respectively. The methylenic protons $\left(\mathrm{CH}_{2}\right)$ of $n$-butyl derivatives (III, IV) show multiplets in the range of $1.40-1.50 \mathrm{ppm}$. In triphenyltin

TABLE-1

PHYSICAL DATA OF ORGANOTIN(IV) COMPLEXES WITH 4-HYDROXYPIPERIDINE

\begin{tabular}{|c|c|c|c|c|c|c|}
\hline \multirow{2}{*}{ Compound No. } & \multirow{2}{*}{ m.f. } & \multirow{2}{*}{ m.p. $\left({ }^{\circ} \mathrm{C}\right)$} & \multirow{2}{*}{ Yield (\%) } & \multicolumn{3}{|c|}{ Elemental analysis calcd. (found) (\%) } \\
\hline & & & & $\mathrm{C}$ & $\mathrm{H}$ & $\mathrm{N}$ \\
\hline $\mathrm{Me}_{2} \mathrm{Sn}(\mathrm{OL})_{2}(\mathbf{I})$ & $\mathrm{C}_{12} \mathrm{H}_{26} \mathrm{~N}_{2} \mathrm{O}_{2} \mathrm{Sn}$ & 250 & 57 & $41.3(40.9)$ & $7.4(5.9)$ & $8.0(7.8)$ \\
\hline $\mathrm{Me}_{3} \operatorname{SnOL}(\mathbf{I I})$ & $\mathrm{C}_{8} \mathrm{H}_{19} \mathrm{NOSn}$ & 56 & 49 & $37.0(36.8)$ & $7.1(6.9)$ & $5.3(4.7)$ \\
\hline$n-\mathrm{Bu}_{2} \mathrm{Sn}(\mathrm{OL})_{2}($ III $)$ & $\mathrm{C}_{18} \mathrm{H}_{38} \mathrm{~N}_{2} \mathrm{O}_{2} \mathrm{Sn}$ & 100 & 65 & $49.8(49.1)$ & $8.7(7.9)$ & $6.4(5.7)$ \\
\hline$n-\mathrm{Bu}_{3} \mathrm{SnOL}(\mathbf{I V})$ & $\mathrm{C}_{17} \mathrm{H}_{31} \mathrm{NOSn}$ & 64 & 64 & $53.1(52.1)$ & $8.7(7.0)$ & $3.6(2.9)$ \\
\hline $\mathrm{Ph}_{2} \mathrm{Sn}(\mathrm{OL})_{2}(\mathbf{V})$ & $\mathrm{C}_{22} \mathrm{H}_{20} \mathrm{~N}_{2} \mathrm{O}_{2} \mathrm{Sn}$ & 230 & 68 & $55.8(55.5)$ & $6.3(5.9)$ & $5.9(5.5)$ \\
\hline $\mathrm{Ph}_{3} \mathrm{SnOL}(\mathrm{VI})$ & $\mathrm{C}_{23} \mathrm{H}_{25} \mathrm{NOSn}$ & 98 & 70 & $61.3(57.4)$ & $5.5(4.3)$ & $3.1(9.6)$ \\
\hline
\end{tabular}


TABLE-3

${ }^{1} \mathrm{H}$ NMR DATA OF ORGANOTIN(IV) COMPLEXES WITH 4-HYDROXYPIPERIDINE ${ }^{\mathrm{a}, \mathrm{b}, \mathrm{c}}$

\begin{tabular}{|c|c|c|c|c|c|}
\hline Proton No. & $\mathrm{LOH}$ & $\mathrm{Me}_{3} \mathrm{SnOL}(\mathbf{I I})$ & $n-\mathrm{Bu}_{2} \mathrm{Sn}(\mathrm{OL})_{2}($ III $)$ & $n-\mathrm{Bu}_{3} \mathrm{SnOL}(\mathbf{I V})$ & $\mathrm{Ph}_{3} \mathrm{SnOL}(\mathbf{V I})$ \\
\hline $\mathrm{O}-\mathrm{H}$ & $4.94(\mathrm{~s})$ & - & - & - & - \\
\hline $\mathrm{N}-\mathrm{H}$ & $4.11(\mathrm{~s})$ & $4.11(\mathrm{~s})$ & $4.11(\mathrm{~s})$ & $4.11(\mathrm{~s})$ & $3.74(\mathrm{~s})$ \\
\hline $4 \mathrm{H}$ & $3.72(\mathrm{~m})$ & $3.50(\mathrm{~m})$ & $3.73(\mathrm{~m})$ & $3.60(\mathrm{~m})$ & $3.73(\mathrm{~m})$ \\
\hline $3 \mathrm{H}^{\mathrm{e}}$ & $1.94(\mathrm{~m})$ & $1.73(\mathrm{~m})$ & $1.95(\mathrm{~m})$ & $1.98(\mathrm{~m})$ & $1.94(\mathrm{~m})$ \\
\hline $2 \mathrm{H}^{\mathrm{e}}$ & $3.11(\mathrm{~m})$ & $3.46(\mathrm{~m})$ & $3.10(\mathrm{~m})$ & $3.12(\mathrm{~m})$ & $3.11(\mathrm{~m})$ \\
\hline $6 \mathrm{H}^{\mathrm{e}}$ & $3.07(\mathrm{~m})$ & $3.47(\mathrm{~m})$ & $3.07(\mathrm{~m})$ & $3.16(\mathrm{~m})$ & $3.08(\mathrm{~m})$ \\
\hline $5 \mathrm{H}^{\mathrm{e}}$ & $1.88(\mathrm{~m})$ & $1.72(\mathrm{~m})$ & $1.74(\mathrm{~m})$ & $1.72(\mathrm{~m})$ & $1.90(\mathrm{~m})$ \\
\hline $3 \mathrm{H}^{\mathrm{a}}$ & $1.44(\mathrm{~m})$ & $1.33(\mathrm{~m})$ & $1.43(\mathrm{~m})$ & $1.39(\mathrm{~m})$ & $1.48(\mathrm{~m})$ \\
\hline $2 \mathrm{H}^{\mathrm{a}}$ & $2.65(\mathrm{~m})$ & $2.86(\mathrm{~m})$ & $2.65(\mathrm{~m})$ & $2.62(\mathrm{~m})$ & $2.63(\mathrm{~m})$ \\
\hline $6 \mathrm{H}^{\mathrm{a}}$ & $2.58(\mathrm{~m})$ & $2.52(\mathrm{~m})$ & $2.58(\mathrm{~m})$ & $2.59(\mathrm{~m})$ & $2.58(\mathrm{~m})$ \\
\hline $5 \mathrm{H}^{\mathrm{a}}$ & $1.37(\mathrm{~m})$ & $1.37(\mathrm{~m})$ & $1.36(\mathrm{~m})$ & $1.36(\mathrm{~m})$ & $1.37(\mathrm{~m})$ \\
\hline$\alpha$ & - & $0.50(\mathrm{~s})[68]$ & $1.69(\mathrm{t} 6.2)[82]$ & $1.70(\mathrm{t} 6.4)[63]$ & $7.28(\mathrm{~m})$ \\
\hline$\beta$ & - & - & $1.40-1.50(\mathrm{~m})$ & $1.40-150(\mathrm{~m})$ & $7.29(\mathrm{~m})$ \\
\hline$\gamma$ & - & - & $1.40-1.50(\mathrm{~m})$ & $1.40-1.50(\mathrm{~m})$ & $7.47(\mathrm{~m})$ \\
\hline
\end{tabular}

(a) Chemical shifts $(\delta)$ in ppm, ${ }^{2} J\left[{ }^{1 \prime} \mathrm{Sn},{ }^{l} \mathrm{H}\right]$ are

listed in square brackets.

(b)

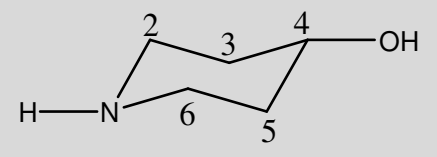

(c)



(d) $\mathrm{a}=$ axial $\mathrm{H}$, (e) equatorial $\mathrm{H}$.

derivative (VI) a complex multiplet pattern is observed in the range 7.28-7.69 ppm due to phenyl groups of the complexes. The $\mathrm{C}-\mathrm{Sn}-\mathrm{C}$ bond angle has been calculated by using Lockhart's and Holeèek et al equations for compound (II, IV, VI) and are $128^{\circ}, 134^{\circ}$ and $115^{\circ}$, respectively. The bond angles calculated support the tetrahedral geometry around tin for triorganotin(IV) derivatives and five-coordinated geometry for diorganotin(IV) derivatives ${ }^{16,17,22}$.

${ }^{13} \mathrm{C}$ NMR spectroscopy: ${ }^{13} \mathrm{C}$ NMR chemical shift values obtained for free ligand (HOL) and respective di- and triorganotin(IV) derivatives are listed in the Table-4. The number of signals observed for ligand corresponds to the presence of expected magnetically non-equivalent carbon atoms ${ }^{12}$. In the spectrum of ligand carbon (4) resonates at $68.41 \mathrm{ppm}$, while carbons $(2,6)$ being magnetically equivalent were observed as a single speak at $44.40 \mathrm{ppm}$. The assignment of ${ }^{13} \mathrm{C}$ signal for carbons $(3,5)$ observed at $36.00 \mathrm{ppm}$. In the ${ }^{13} \mathrm{C}$ spectra of triphenyltin and tri- $n$-butyltin and methyltin derivatives resonance due to all carbon atoms are visible and appeared in expected regions as shown in the Table $-4^{19}$.

The signals of $\mathrm{R}$ groups attached to $\mathrm{Sn}$ atom, were assigned by comparing with literature values ${ }^{24,25}$. The magnitudes of ${ }^{n} J\left[{ }^{119} \mathrm{Sn},{ }^{13} \mathrm{C}\right]$ couplings constant in compounds (II, III, VI) are also observed for trimethyl, triphenyl and tri- $n$-butyltin(IV) derivatives with the ${ }^{1} J\left[{ }^{119} \mathrm{Sn},{ }^{13} \mathrm{C}\right], 532,625$ and $598 \mathrm{~Hz}$, respectively. By using Holeèek equations ${ }^{23} \mathrm{C}$-Sn-C bond angles were calculated fond $123^{\circ}, 134^{\circ}$ and $115^{\circ}$ for (II, III, VI), respectively ${ }^{23}$, which corresponds to tetrahedral geometry in $\mathrm{CDCl}_{3}$ for triphenyl- (VI) and five coordinated environment around the tin atom for trimethyl- (II) and di- $n$-butyltin(IV) alkoxides in (DMSO).
${ }^{119}$ Sn NMR spectroscopy: ${ }^{19} \mathrm{Sn}$ NMR spectroscopy is most convenient technique used to study organotin(IV) derivatives in solution and in the solid state. The ${ }^{119} \mathrm{Sn}$ nucleus has natural abundance of $8.7 \%$ and is 25 times more sensitive than ${ }^{13} \mathrm{C}$ nucleus. ${ }^{119} \mathrm{Sn}$ NMR spectra were recorded in $\mathrm{CDCl}_{3}$ solution, chemicals shift data is presented in the Table-4. The $\delta\left({ }^{119} \mathrm{Sn}\right)$ chemical shifts of compounds (II, IV, VI) are observed at $-84,-48$ and $-32 \mathrm{ppm}$, reflecting tetrahedral geometries around the tin moiety in solution ${ }^{27-29}$. The $\delta\left({ }^{119} \mathrm{Sn}\right)$ chemical shift of compound (III) is observed at -158 ppm, suggesting a five coordinated geometry around tin.

Antibacterial activity: The synthesized compounds were screened for antibacterial activity against Escherichia coli, Bacillus subtilis, Shigella flexenari, Staphylococcus aureus, Pseudomonas aeruginosa and Salmonella typhi bacterial strains, using the agar well diffusion method ${ }^{30}$. Imipenum was used as a standard drug and the wells (6 $\mathrm{mm}$ in diameter) were dug in the media with the help of a sterile metallic borer. Two to eight hours old bacterial inoculums containing approximately $10^{4}-10^{6}$ colony-forming units $(\mathrm{CFU}) / \mathrm{mL}$ were spread on the surface of a nutrient agar with the help of a sterile cotton swab. The recommended concentration of the test sample (200 $\mathrm{mg} / \mathrm{mL}$ in DMSO) was introduced into the respective wells. Other wells supplemented with DMSO and reference antibacterial drug served as negative and positive controls, respectively. The plates were incubated immediately at $37{ }^{\circ} \mathrm{C}$ for $20 \mathrm{~h}$. The activity was determined by measuring the diameter of the inhibition zone (in $\mathrm{mm}$ ), showing complete inhibition. Growth inhibition was calculated with reference to the positive control. The results of the antibacterial activity so obtained are collected in the Table-5. 


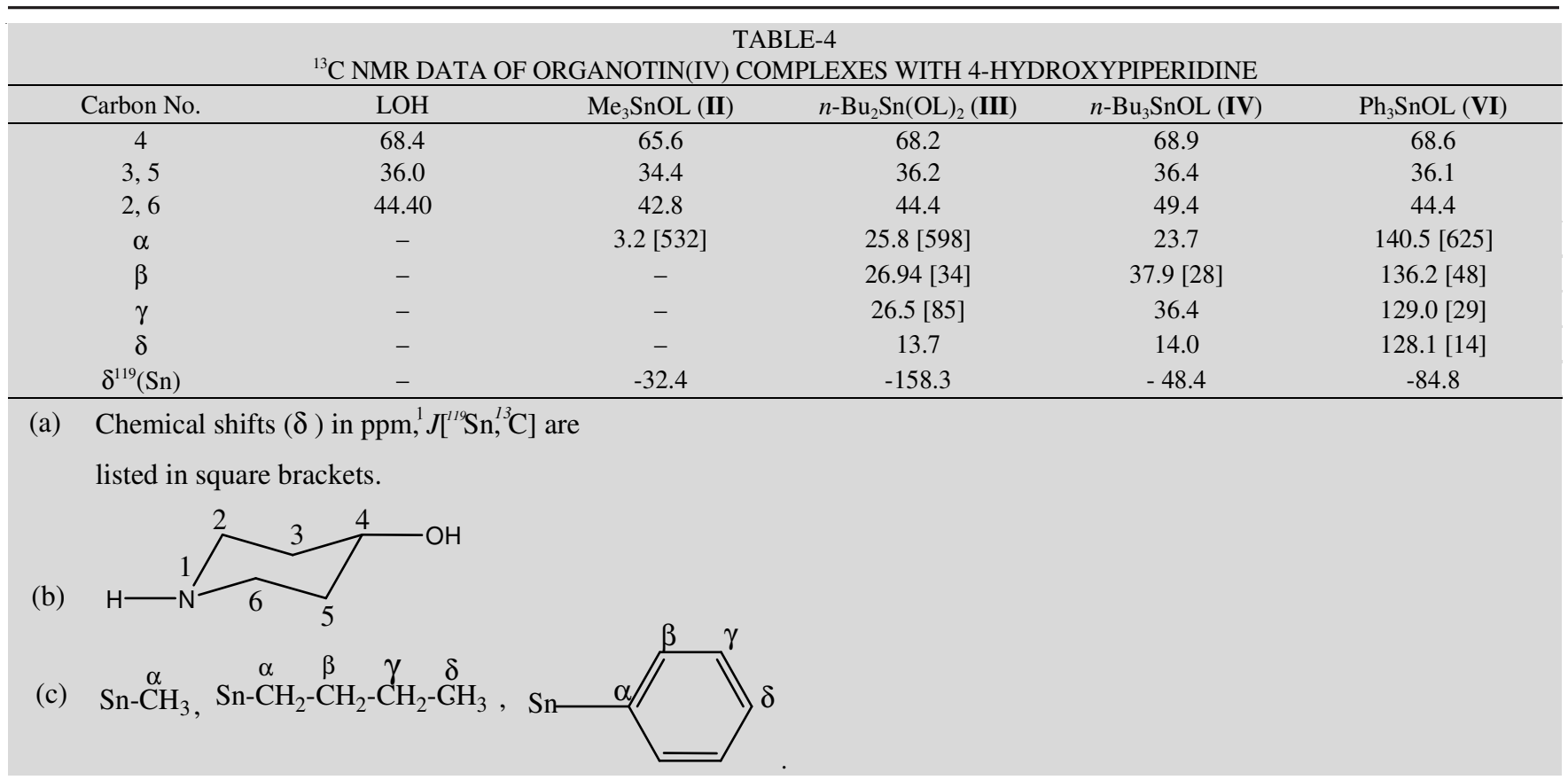

The free ligand show non-significant activity against Pseudomonas aeruginosa. The investigated compounds (IIIVI) show significant activity against Eschericha coli, Bacillus subtilis, Salmonella typhi, Staphylococcus aureus and gives low activity against Shigella flexenari and Pseudomonas aeruginosa. Compound (II) observed to have low activity against Shigella flexenari and non significant activity against Staphylococcus aureus and Pseudomonas aerugiosa, while compound (I) shows good activity against Staphylococcus aureus, Pseudomonas aeruginosa and low activity against Shigella flexenaria and Salmonella thphi and non-significant activity against Eschericha coli and Bacilius subtilis.

Antifungal activity: The synthesized organotin derivatives were also tested for antifungal activity against six different human, animal and plant pathogens, namely Trichophyton longifusus, Candida albicans, Aspergillus flavus, Microsporum canis, Fusarium solani and Candida glaberata by using the tube diffusion test ${ }^{31}$. Amphotericin B and miconazole were used as standard antifungal agents for the comparison test. Stock solutions of pure compounds $(200 \mathrm{~g} / \mathrm{mL})$ were prepared in sterile DMSO. Sabouraud dextrose agar was prepared by mixing Sabouraud (32.5 g), glucose agar (4\%) and agar-agar $(4 \mathrm{~g})$ in $500 \mathrm{~mL}$ of distilled water followed by dissolution at 90-95 ${ }^{\circ} \mathrm{C}$ on a water bath. The media $(4 \mathrm{~mL})$ was dispensed into screw-capped tubes and autoclaved at $121^{\circ} \mathrm{C}$ for $15 \mathrm{~min}$.
Test compounds $(66.6 \mathrm{~mL})$ were added from the stock solution to nonsolidified Sabouraud agar media $\left(50^{\circ} \mathrm{C}\right)$. The tubes were then solidified at room temperature and inoculated with $4 \mathrm{~mm}$ diameter portion of inoculums derived from a 7-days old respective fungal culture. For nonmycelial growth, an agar surface streak was employed. The tubes were incubated at $27-29^{\circ} \mathrm{C}$ for $7-10$ days and growth in the compound containing media was determined by measuring the linear growth (in $\mathrm{mm}$ ) and growth inhibition with reference to the respective control.

The fungicidal screening data for the tested compounds are listed in Table-6. The free ligand 4-hydroxypiperidine shows moderate activity against Trichophyton longifusus, Aspergillus flavus and Fusarium solani. While compounds (I, VI) show significant activity against all the tested fungi. Compounds (I, III, V) show significant activity against Trichphyton longifusus, Aspergillus flavus, Microsportum canis, Fusarium solani, Candida glabrata and Candida albicans.

Cytotoxicity: For all the synthesized complexes, including ligand, $\mathrm{LD}_{50}$ values were measured and compared with standard drug etoposide to evaluate their toxicity. The cytotoxicity data have been collected by the brine-shrimp lethality bioassay method $^{31}$ and the results are summarized in the Table-7. It has been noted that free ligand has a positive lethality, while compounds $(\mathbf{V}, \mathbf{V I})$ show cytotoxicity at the highest dose only.

\section{TABLE-5}

ANTIBACTERIAL ACTIVITY DATA OF ORGANOTIN(IV) COMPLEXES WITH 4-HYDROXYPIPERIDINE

\begin{tabular}{|c|c|c|c|c|c|c|c|c|}
\hline \multirow[b]{2}{*}{ Name of bacterium } & \multicolumn{7}{|c|}{ Zone of inhabitation $(\mathrm{nm})$} & \multirow[b]{2}{*}{ Ref. } \\
\hline & HOL & $\begin{array}{c}\mathrm{Me}_{2} \mathrm{Sn}(\mathrm{OL})_{2} \\
\text { (I) }\end{array}$ & $\begin{array}{c}\mathrm{Me}_{3} \mathrm{SnOL} \\
\text { (II) }\end{array}$ & $\begin{array}{c}n-\mathrm{Bu}_{2} \mathrm{Sn}(\mathrm{OL})_{2} \\
\text { (III) }\end{array}$ & $\begin{array}{c}n-\mathrm{Bu}_{3} \mathrm{SnOL} \\
(\mathbf{I V})\end{array}$ & $\begin{array}{c}\mathrm{Ph}_{2} \mathrm{Sn}(\mathrm{OL})_{2} \\
(\mathbf{V})\end{array}$ & $\begin{array}{c}\mathrm{Ph}_{3} \mathrm{SnOL} \\
(\mathbf{V I})\end{array}$ & \\
\hline Escherishia coli & - & 10 & - & 19 & 42 & 18 & 20 & 25 \\
\hline Bacillus subtilis & - & 11 & - & 17 & 42 & 17 & 21 & 26 \\
\hline Shigella flexenari & - & 12 & 14 & 10 & 12 & 13 & 12 & 24 \\
\hline Staphlococcus aureus & - & 16 & 10 & 19 & - & 18 & - & 17 \\
\hline Pseudomona aeruginosa & 11 & 16 & 10 & 13 & 14 & 11 & - & 17 \\
\hline Salmonella typhi & - & 13 & 21 & 17 & - & 21 & 22 & 21 \\
\hline
\end{tabular}


TABLE-6

ANTIFUNGAL ACTIVITY DATA OF ORGANOTIN(IV) COMPLEXES WITH 4-HYDROXYPIPERIDINE ${ }^{\text {abc }}$

\begin{tabular}{|c|c|c|c|c|c|c|c|c|c|}
\hline \multirow[b]{2}{*}{ Name of fungus } & \multicolumn{9}{|c|}{ Inhibition (\%) } \\
\hline & $\begin{array}{c}\mathrm{HO} \\
\mathrm{L}\end{array}$ & $\begin{array}{c}\mathrm{Me}_{2} \mathrm{Sn}(\mathrm{OL}) \\
\text { (I) }\end{array}$ & $\begin{array}{l}\mathrm{Me}_{3} \mathrm{SnO} \\
\mathrm{L}(\mathbf{I I})\end{array}$ & $\begin{array}{c}n-\mathrm{Bu}_{2} \mathrm{Sn}(\mathrm{OL})_{2} \\
\text { (III) }\end{array}$ & $\begin{array}{c}n-\mathrm{Bu}_{3} \mathrm{SnOL} \\
(\mathbf{I V})\end{array}$ & $\begin{array}{c}\mathrm{Ph}_{2} \mathrm{Sn}(\mathrm{OL}) \\
\quad(\mathrm{V})\end{array}$ & $\begin{array}{c}\mathrm{Ph}_{3} \mathrm{SnOL} \\
\text { (VI) }\end{array}$ & Std. Drug $\mu \mathrm{g}$ & $\begin{array}{c}\text { MIC } \\
(\mu \mathrm{g} / \mathrm{mL})\end{array}$ \\
\hline $\begin{array}{l}\text { Trichophyton } \\
\text { longifusus }\end{array}$ & 50 & - & - & - & 20 & 80 & 80 & Miconazole & 70 \\
\hline $\begin{array}{l}\text { Candida } \\
\text { albicans }\end{array}$ & - & - & - & - & 80 & - & 80 & Miconazole & 110.8 \\
\hline $\begin{array}{l}\text { Aspergillus } \\
\quad \text { flarus }\end{array}$ & 50 & - & - & - & 90 & 80 & - & Amphotericin B & 20 \\
\hline $\begin{array}{l}\text { Microsporium } \\
\text { canis }\end{array}$ & 20 & - & - & - & - & 80 & 80 & Miconazole & 98.4 \\
\hline $\begin{array}{l}\text { Fusarium } \\
\text { solani }\end{array}$ & 50 & - & - & - & 90 & 80 & 80 & Miconazole & 73.25 \\
\hline Candida glaberata & - & - & - & - & 80 & - & 80 & Miconazole & 110.8 \\
\hline
\end{tabular}

${ }^{\mathrm{a}} \mathrm{MIC}$, minimum inhibitory concentration. ${ }^{\mathrm{c}}$ Incubation period $=7$ days. ${ }^{\mathrm{b}}$ Concentration, $200 \mu \mathrm{g} / \mathrm{mL}$ of DMSO.

\begin{tabular}{|c|c|c|c|c|c|c|c|}
\hline \multicolumn{8}{|c|}{$\begin{array}{c}\text { TABLE-7 } \\
\text { CYTOTOXICITY DATA OF ORGANOTIN(IV) COMPL }\end{array}$} \\
\hline Compounds & LOH & $\begin{array}{l}\mathrm{Me}_{2} \mathrm{Sn}(\mathrm{OL})_{2} \\
(\mathbf{I})\end{array}$ & $\begin{array}{l}\mathrm{Me}_{3} \mathrm{SnOL} \\
\quad(\text { II })\end{array}$ & $\begin{array}{c}n-\mathrm{Bu}_{2} \mathrm{Sn}(\mathrm{OL})_{2} \\
(\text { IIII })\end{array}$ & $\begin{array}{c}n-\mathrm{Bu}_{3} \mathrm{SnOL} \\
(\mathbf{I V})\end{array}$ & $\begin{array}{c}\mathrm{Ph}_{2} \mathrm{Sn}(\mathrm{OL})_{2} \\
(\mathbf{V})\end{array}$ & $\begin{array}{l}\mathrm{Ph}_{3} \mathrm{SnOL} \\
(\mathbf{V I})\end{array}$ \\
\hline $\mathrm{LD}_{50}$ & 34.6983 & 65.0235 & - & 36.1322 & 0.9271 & - & - \\
\hline
\end{tabular}

Similarly, compounds (I, III, IV) show a positive lethality and compound (II) exhibits no cytotoxicity.

\section{Conclusion}

The elemental analyses results of all the synthesized compounds are comparable with calculated and found values of carbon and hydrogen atoms, which confirmed the formation and purity of compounds. Spectroscopic studies (FT-IR, multinuclear NMR) as well support the formation of products. Furthermore, results obtained by different spectroscopic techniques are consistent with the proposed structures, which probably lead to the conclusion that the synthesized compounds in non-coordinating solvent $\left(\mathrm{CDCl}_{3}\right)$ are monomeric with tetrahedral geometry and in the coordinating solvent (DMSO) are five coordinated.

Biological activity data collected for the investigated compounds show that triorganotin(IV) alkoxides have good activities compared to their diorganotin(IV) analogues. Particularly, tri- $n$-butyltin(IV) complex found to be more effective and potent against all the tested fungi and also showed more activity against few medically important bacteria.

\section{REFERENCES}

1. Aziz-ur-Rehman, S. Ali, M. Najam-ul-Haq, S. Shahzadi and K. Wurst, Acta Cryst., E62, 451 (2006)

2. R.F. Zhang, J. Sun and C.L. Ma, J. Organomet. Chem., 690, 4366 (2005).

3. Imtiaz-ud-Din, M. Mazher, S. Ali, K.C. Molloy, S. Dastgir and M.F. Mohan, Main Group Met.Chem., 25, 315 (2002).

4. M. Mazhar, K.M. Khan and K.C. Molloy, J. Organomet. Chem., 689 , 899 (2000).

5. K.C. Molloy, T.J. Purcell, E. Hahn, H. Schumann and J. Zuckerman, J. Organometallics, 5, 85 (1986).

6. Sadiq-ur-Rehman, S. Ali and S. Shahzadi, Hetroatom Chem., 19, 612 (2008).

7. Sadiq-ur-Rehman, S. Ali, S. Shahdadi, A. Malik and E. Ahmed, Turk. J. Chem., 31, 371 (2007).
8. S. Yaqub, F. Ahmed, Sadiq-ur-Rehman, S. Ali and S. Shahzadi, J. Iran. Chem., Soc., 6, 88 (2009).

9. W.L.F. Armarego and C.L.L. Chai, Purification of Laboratory Chemical, Pergamon, Oxford, edn. 4 (1997).

10. W.L.F. Armarego and C.L.L. Chai, Purification of Laboratory Chemical, Butterworth-Heinemann, London, New York, edn. 4 (2003).

11. A. Altmore, M. Cascarano, C. Giacovazzo and A. Guagliardi, J. Appl. Cryst., 26, 343 (1993).

12. Q. Xie, Z. Yang and L. Jiang, Main Group Met. Chem., 19, 509 (1996).

13. G.B. Deacon, J. Coord. Chem. Rev., 33, 227 (2000).

14. G. Singh and V.D. Gupta, Nat. Acad. Sci. Lett. India, 5, 423 (1982).

15. E.R.T. Tiekink, Appl. Organomet. Chem., 1, 5 (1991).

16. H. Friebulin, Basic One- and Two-Dimensional NMR Spectroscopy, VCH: Weinheim, New York, edn. 2, 60 (1993).

17. T.P. Lockhart, W.F. Manders and E.M. Holt, J. Am. Chem. Soc., 108, 6611 (1986)

18. M.H. Bhatti, S. Ali, H. Masood, M. Mazhar, S.I. Qurashi, Synth. React. Inorg. Met.-Org. Chem., 30, 1715 (2000).

19. S. Ali, F. Ahmed, M. Mazhar, A. Munir and M.T. Masood, Synth. React. Inorg. Met-Org. Chem., 32, 357 (2002).

20. Sadiq-ur-Rehman, K. Shahid, S. Ali, M.H. Bhatti and M. Pervez, J. Organomet. Chem., 690, 1396 (2005).

21. Sadiq-ur-Rehman, S. Ali, M. Mazher, A. Badshah and M. Pervez, Hetroatom Chem., 17, 420 (2006).

22. F. Ahmed, S. Ali, M. Pervez, M. Mazhar and T.A. Shah, Hetroatom Chem., 13, 683 (2002).

23. J. Holeèek and A. Lyeka, Inorg. Chim. Acta., L15, 118 (1996).

24. K. Shahid, S. Ali, A. Badshah, K.M. Khan and G.M. Maharvi, Synth. React. Inorg. Met.-Org. Chem., 33, 1221 (2003).

25. Sadiq-ur-Rehman, S. Ali, A. Badshah, A. Malik, E. Ahmed, G.X. Jin and E.R. Tiekink, Appl. Organomet. Chem., 18, 401 (2004).

26. K. Shahid, S. Ali, A. Badshah, K.M. Khan and G.M. Maharvi, Synth. React. Inorg. Met-Org. Chem., 33, 1221 (2003).

27. J. Holeèek, M. Nadvornik and R. Handlir, J. Organomet. Chem., 241, 77 (1983).

28. D. Dakernick, H. Zhu, D. Masi and C. Mealli, Inorg. Chem., 31, 3601 (1992).

29. W.P. Neumann, The Organic Chemistry of Tin, Interscience Publisher, John Wiley \& Sons, London, New York (1970).

30. S.S. Shaukat, N.A. Khan and F. Ahmad, Pak. J. Bot., 12, 97 (1980).

31. B.N. Meyer, R. Ferrigni, J.E. Putnam, L.B. Jabcobson, D.E. Nichols and M.C.J.L. Laughlin, Planta Med., 31, 45 (1982). 